\title{
THE ROLE OF PROFITABILITY IN MEDIATING INFLUENCES GOOD CORPORATE GOVERNANCE, BUSINESS RISK, CORPORATE SOCIAL RESPONSIBILITY AND FIRM VALUE OF BANKING COMPANIES LISTED IN INDONESIA STOCK EXCHANGE
}

\author{
Purbawangsa Ida Bagus Anom, Suprasto Herkulanus Bambang \\ Faculty of Economics and Business, University of Udayana, Bali, Indonesia \\ *E-mail: gidabagus@unud.ac.id
}

\begin{abstract}
Banks are intermediary institutions between parties who are overfunded and those who need funds. Banking management activities are based on trust. The main goal in business is to maximize the value of the company (value of the firm). Achieving maximum company value depends on internal factors and macroeconomic factors. Previous research linking Business Risk, Good Corporate Governance (GCG) and Corporate Social Responsibility (CSR) to profitability and the value of the company showed different results. Based on this research gap the researcher will try to use the profitability variable as a mediating variable. The method of data collection is the nonparticipant observation method. Secondary data in the form of financial statements of banking companies listed on the Indonesia Stock Exchange from 2015 to 2018. Taking samples using purposive sampling. Based on the sampling criteria obtained 104 banks as research samples. The data analysis technique used is path analysis. The test results show that: (1) business risk has a significant positive effect on profitability, (2) business risk has no significant effect on firm value, (3) GCG has a significant positive effect on profitability, (4) GCG has a significant positive effect on firm value, (5) CSR has a significant positive effect on profitability, (6) CSR has no significant effect on firm value, (7) Profitability has a significant positive effect on firm value, (8) Profitability is able to mediate the effect of business risk on firm value, (9) Profitability is able to mediate the effect of GCG on firm value, (10) Profitability is able to mediate the effect of CSR on firm value.
\end{abstract}

\section{KEY WORDS}

Business risk, good corporate governance, corporate social responsibility, firm value.

Company Value can be used as a benchmark for the performance of a company on implementation where financial functions and companies that have good values have good performance (Tikawati, 2016). It is important to pay attention to the company's value of a company because that value is a picture of the prosperity of the company owner (Hidayah, 2014). A conflict of interest will arise when the manager acts to prioritize personal interests by abusing his authority and ultimately sacrificing the interests of shareholders, this is usually called an agency conflict. Agency theory Jensen and Meckling (1976) that agency problems will arise when shareholders rely on managers in terms of services on behalf of the company and how to solve them by aligning the interests of the majority and minority.

The importance of proper company management is done in order to reduce conflicts of interest between majority and minority, Corporate Governance is a mechanism that can balance the actions or choices of managers with the interests of shareholders (Susanti, 2011), the Government in collaboration with Bank Indonesia has created efforts to realize good Corporate Governance in the banking environment. In 2006, BI issued Bank Indonesia Regulation No. 8/4 / PBI / 2006 on January 30, 2006, discusses the GCG Implementation of commercial banks in addition to the legal provisions of Bank Indonesia.

Corporate Responsibility is the foundation that makes the company not confronted with responsibilities that are grounded in economic aspects that can be reflected in its financial condition, CSR can minimize adverse impacts on social and environmental aspects caused during carrying out company activities. CSR has enormous benefits for the survival of the company. By implementing CSR the company will get a positive image in the community and this is an important thing in company activities with a good public image. (Branco and 
Rodrigues, 2006).

Profitability is the result of some policies carried out by the company. The ratio will show how effective the company's operations are. Investors will always pay attention to any changes in the value of banking profitability in Indonesia because these changes will affect the value of the company. High profitability will cause a reaction in the form of a positive response by buying the company's shares. Companies that carry out and disclose Corporate Social Responsibility (CSR) and implement Good Corporate Governance (GCG) are expected to be able to influence profitability so that the company's main goal is to maximize the value of the company can be realized

Research on corporate value has been widely carried out and research on GCG conducted by Cheung et al (2008) found that the higher the company's image in implementing GCG, the higher the company's value. In contrast to the results of empirical research conducted by Ragers et al. (2009) which proves that GCG does not affect firm value. Research conducted by Ardi (2016) found that GCG had a positive effect on the profitability of conventional commercial banks, while Ragers, et al (2009) stated that GCG did not affect profitability.

Research conducted by Ayu (2014) proves that Business Risk will be reduced if the company pays more attention to the level of the amount of the degree of operating leverage to avoid the risk of future debt ratios by suppressing the amount of debt used by using company capital so that the risk level of (DOL) will be reduced. Research conducted by Ayu (2014) and Wijaya (2011) found that business risk had a positive and significant effect on profitability.

Research conducted by Crisostomo, et al (2011) proves that Corporate Social Responsibility can cause a market reaction accompanied by an increase in the company's stock market price which means it can increase the value of the company and research conducted by Agustina (2013), Rustiarini (2010) and Kusumadilaga (2010) get the results that CSR has a significant positive effect on firm value. In contrast to the results of research conducted by Fiori, et al (2007) which proves that CSR does not affect firm value. Research on profitability also gets different results. Research by Byus, et al (2010) found that Corporate Social Responsibility has a positive effect on profitability, while the results of Susilowati's research (2008) prove that CSR does not affect profitability.

The inconsistencies that occur in the results of Good Corporate Governance and Corporate Social Responsibility research on the company's previous values are the reasons for conducting this research by adding profitability as a mediating variable. Profitability is assumed to be another variable that also affects the relationship of GCG variables with firm value and the relationship of CSR variables with company value becomes an indirect relationship. Profitability is expected to be able to mediate the effect of GCG and CSR on company value because there is a positive influence between GCG and CSR with profitability and firm value.

GCG can increase company profitability because GCG implementation can minimize conflicts of interest between Majority and Minority. Conflicts of interest, if it can be minimized, will make managers optimize profits because the better the quality of the company's earnings can increase profitability. CSR is widely able to increase profitability because a good reputation will be formed and the company's products will be better known by the public so that the company's profits will increase. The increase in profits is directly related to the profitability of the company.

This study uses endogenous variables, the company value to examine whether these variables are influenced by Good Corporate Governance, Business Risk and Corporate Social Responsibility with profitability as a mediating variable, profitability is one indicator that is very often used by stakeholders in determining and making decisions that will be an impact on Company Value, the variable was chosen because there are still differences in research results, then this is a gap for researchers to conduct further research, so this study raised the research title "The Role of Profitability in Mediating the Effects of Good Corporate Governance, Business Risk and Corporate Social Responsibility to Firms Value of Banking Companies in the Indonesia Stock Exchange". 
Hypotheses:

- H1: Business Risk has a significant positive effect on profitability;

- H2: Business Risk has a significant negative effect on Company Value;

- H3: Good Corporate Governance has a positive and significant effect on profitability;

- H4: Good Corporate Governance has a positive and significant effect on Company Value;

- H5: Corporate Social Responsibility has a positive and significant effect on profitability;

- H6: Corporate Social Responsibility has a positive and significant effect on Company Value;

- H7: Profitability has a significant positive effect on firm value;

- H8: Profitability can mediate the effect of Business Risk on Company Value;

- H9: Profitability can mediate the effect of Good Corporate Governance on Company Value;

- H10: Profitability can mediate the influence of Corporate Social Responsibility on the value of the company.

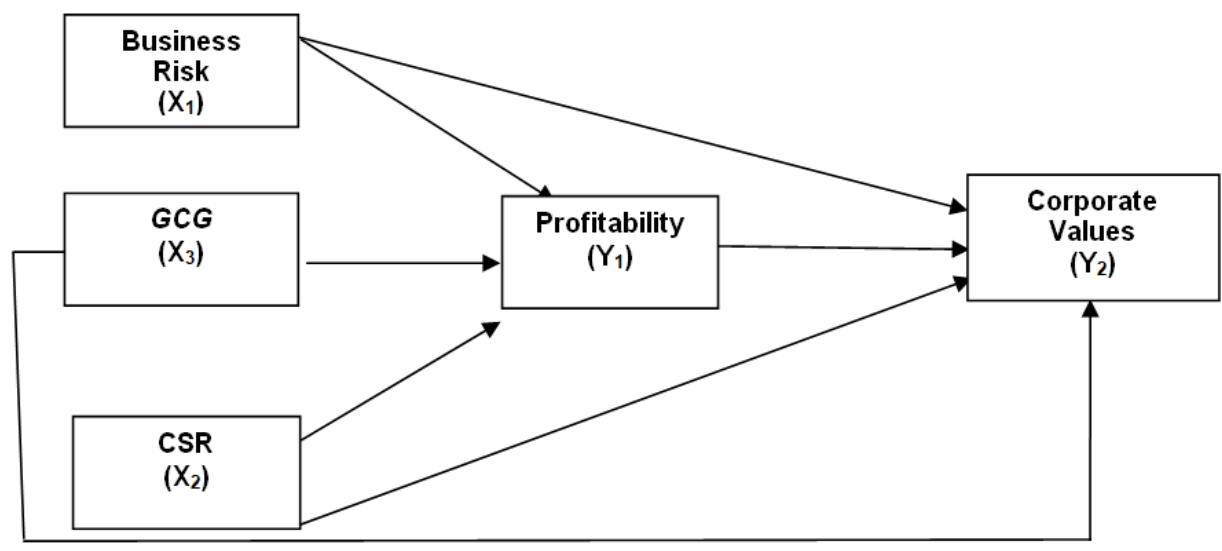

Figure 1 - Research Conceptual Framework

\section{METHODS OF RESEARCH}

This research is classified as quantitative research which is directed to test certain theories. Testing is done by examining the relationship between research variables. The locations of this research are banking sector companies listed on the Indonesia Stock Exchange, by accessing the website www.idx.co.id. The population of this study is all banking companies listed on the Indonesia Stock Exchange from 2015 to 2018.

The sample criteria used in this study are:

- Banks operating using the conventional system for the period 1 January 2015 to 31 December 2018;

- Banking companies that publish full annual reports including disclosure of Corporate Social Responsibility and are available to the public.

Table 1 - Number of Research Samples

\begin{tabular}{|c|l|c|}
\hline No & \multicolumn{1}{|c|}{ Information } & Total \\
\hline 1 & Number of Banking Companies on the Indonesia Stock Exchange Period 2014 - 2018 & 168 \\
\hline 2 & $\begin{array}{l}\text { Banks that do not operate using the conventional system for the period of 1 January 2014 to 31 } \\
\text { December 2018 }\end{array}$ & $(4)$ \\
\hline 3 & $\begin{array}{l}\text { Banking companies that do not publish complete annual reports include disclosure of Corporate Social } \\
\text { Responsibility and are available to the public }\end{array}$ & $(60)$ \\
\hline \multicolumn{2}{|c|}{ Total of Sample } & 104 \\
\hline
\end{tabular}


The data collection method used in this study is a non-participant observation method, which is a technique used to collect data by observation where the researcher is not directly involved (Sugiyono, 2009: 204). The data analysis technique used in this study is to use path analysis. Path analysis can be done using the SPSS (Statistical Package for Social Science) program.

\section{RESULTS OF STUDY}

Descriptive statistics used in this study can provide a general description of the object of research in the sample. This descriptive statistical explanation is expected to provide an initial understanding of the research problem. Research which uses independent variables and which dependent variable. Good Corporate Governance (X1) and Corporate Social Responsibility (X2) variables are independent variables. Company Value Variable (Y2) is the dependent variable and the mediating variable in this study is Profitability (Y1) which can be proxied by Return on Assets (Y1). Descriptive statistics of each variable are shown in Table 2 below:

Table 2 - Descriptive Statistics

\begin{tabular}{|c|c|c|c|c|c|c|}
\hline \multicolumn{7}{|c|}{ Statistics } \\
\hline & & $\operatorname{GCG}(X 1)$ & $\operatorname{CSR}(X 2)$ & RISK (X3) & $\mathrm{ROA}(\mathrm{Y} 1)$ & PBV (Y2) \\
\hline \multirow[t]{2}{*}{$\mathrm{N}$} & Valid & 130 & 130 & 130 & 130 & 130 \\
\hline & Missing & 0 & 0 & 0 & 0 & 0 \\
\hline \multicolumn{2}{|c|}{ Mean } & 1.95981 & .52718 & 8.80892 & 1.30185 & 1.48415 \\
\hline \multicolumn{2}{|c|}{ Std. Error of Mean } & .047056 & .008628 & .443904 & .063159 & .072959 \\
\hline \multicolumn{2}{|c|}{ Median } & 1.90000 & .53333 & 7.36000 & 1.15500 & 1.23000 \\
\hline \multicolumn{2}{|c|}{ Mode } & 2.700 & .533 & 5.530 & 1.940 & $1.070^{a}$ \\
\hline \multicolumn{2}{|c|}{ Std. Deviation } & .536520 & .098375 & 5.061286 & .720126 & .831863 \\
\hline \multicolumn{2}{|c|}{ Variance } & .288 & .010 & 25.617 & .519 & .692 \\
\hline \multicolumn{2}{|c|}{ Range } & 2.150 & .467 & 24.230 & 3.030 & 3.980 \\
\hline \multicolumn{2}{|c|}{ Minimum } & 1.225 & .333 & .590 & .080 & .350 \\
\hline \multicolumn{2}{|c|}{ Maximum } & 3.375 & .800 & 24.820 & 3.110 & 4.330 \\
\hline \multicolumn{2}{|c|}{ Sum } & 254.775 & 68.533 & 1145.160 & 169.240 & 192.940 \\
\hline
\end{tabular}

a. Multiple modes exist. The smallest value is shown

Source: Data Processed.

The estimation results of the structural model I are shown in Table 4.10. Based on Table 4.10 it can be seen that the business risk, GCG, and CSR respectively partially have a significant positive effect on profitability at $\alpha=5 \%$.

Table 3 - Estimation Result Model of Structure 1

Coefficients ${ }^{\mathrm{a}}$

\begin{tabular}{|c|c|c|c|c|c|c|c|c|}
\hline \multirow{2}{*}{\multicolumn{2}{|c|}{ Model }} & \multicolumn{2}{|c|}{$\begin{array}{l}\text { Unstandardized } \\
\text { Coefficients }\end{array}$} & \multirow{2}{*}{$\begin{array}{c}\begin{array}{c}\text { Standardized } \\
\text { Coefficients }\end{array} \\
\text { Beta }\end{array}$} & \multirow[b]{2}{*}{$t$} & \multirow[b]{2}{*}{ Sig. } & \multicolumn{2}{|c|}{ Collinearity Statistics } \\
\hline & & $\mathrm{B}$ & Std. Error & & & & Tolerance & VIF \\
\hline & (Constant) & -.314 & .135 & & -2.325 & .022 & & \\
\hline & GCG (X1) & .078 & .039 & .058 & 1.998 & .048 & .999 & 1.001 \\
\hline & $\operatorname{CSR}(\mathrm{X} 2)$ & .610 & .226 & .083 & 2.702 & .008 & .881 & 1.134 \\
\hline & RISK (X3) & .130 & .004 & .911 & 29.555 & .000 & .882 & 1.134 \\
\hline
\end{tabular}

a. Dependent Variable: ROA (Y1)

Source: data processed.

The estimation results of structure model II are shown in Table 4. Based on Table 4, it can be seen that GCG and profitability of each part have a significant positive effect on firm value at $\alpha=5 \%$, while the effect of CSR and business risk on firm value is not significant. 
Table 4 - Estimation result model of Structure II

Coefficients $^{\mathrm{a}}$

\begin{tabular}{|c|c|c|c|c|c|c|c|c|}
\hline \multirow{2}{*}{\multicolumn{2}{|c|}{ Model }} & \multicolumn{2}{|c|}{$\begin{array}{c}\text { Unstandardized } \\
\text { Coefficients }\end{array}$} & \multirow{2}{*}{$\begin{array}{c}\begin{array}{c}\text { Standardized } \\
\text { Coefficients }\end{array} \\
\text { Beta }\end{array}$} & \multirow[b]{2}{*}{$\mathrm{t}$} & \multirow[b]{2}{*}{ Sig. } & \multicolumn{2}{|c|}{ Collinearity Statistics } \\
\hline & & $\mathrm{B}$ & Std. Error & & & & Tolerance & VIF \\
\hline \multirow[t]{5}{*}{1} & (Constant) & .335 & .398 & & .843 & .401 & & \\
\hline & GCG (X1) & .256 & .114 & .165 & 2.243 & .027 & .968 & 1.033 \\
\hline & $\operatorname{CSR}\left(X_{2}\right)$ & -.403 & .670 & -.048 & -.601 & .549 & .833 & 1.200 \\
\hline & RISK (X3) & .022 & .036 & .135 & .623 & .535 & .111 & 8.993 \\
\hline & $\mathrm{ROA}(\mathrm{Y} 1)$ & .511 & .257 & .442 & 1.985 & .049 & .106 & 9.471 \\
\hline
\end{tabular}

a. Dependent Variable: PBV (Y2)

Source: Data Processed.

Based on the Standardized Coefficients Beta values in Table 3 and Table 4 a path diagram can be drawn from the structure model I and structure model II shown in Figure 1.

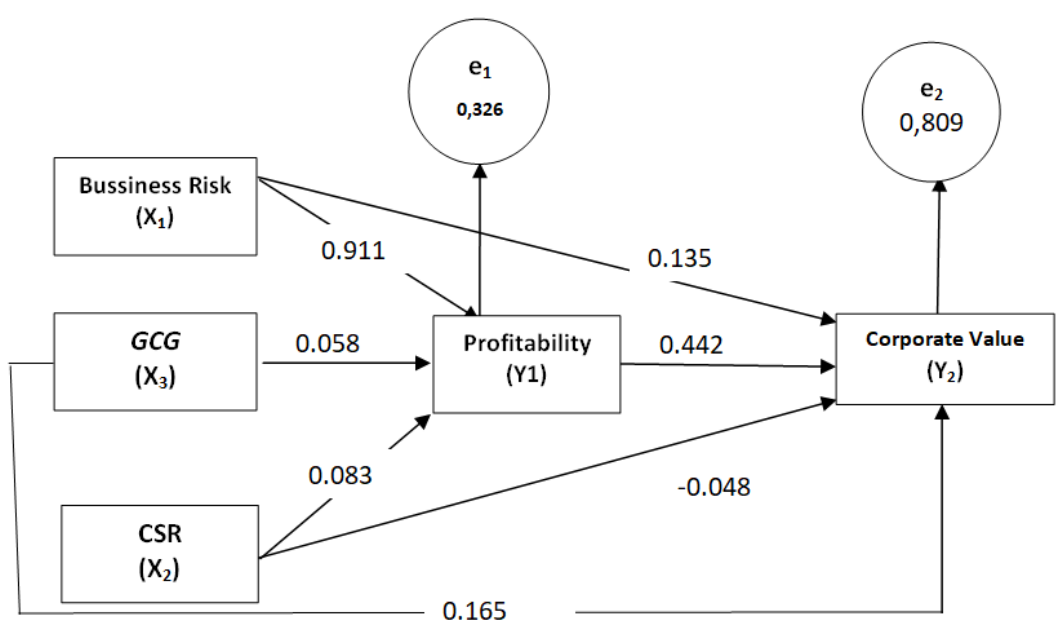

Figure 2 - Path Chart Model

Figure 2 above shows the magnitude of the direct effect of independent variables on the dependent variable. Based on the magnitude of the direct influence between the paths in Figure 1, the magnitude of the indirect effect of the independent variables on the dependent variable through the mediating variables can be calculated. The calculation of indirect effects is shown in Table 5 below.

Table 5 - Indirect Effects through Mediation Variables

\begin{tabular}{lc}
\hline \multicolumn{1}{c}{ Variable } & Indirect Path \\
\hline Business risk $\rightarrow$ Profitability $\rightarrow$ Corporate Value & $0,911 \times 0,442=0,403$ \\
GCG $\rightarrow$ Profitability $\rightarrow$ Corporate Value & $0,058 \times 0,442=0,026$ \\
CSR $\rightarrow$ Profitability $\rightarrow$ Corporate Value & $0,083 \times 0,442=0,037$ \\
\hline
\end{tabular}

Source: Data Processed.

Based on the value of direct and indirect effects, the magnitude of the total influence can be calculated. The magnitude of the effect of the total relationship between the research variables is summarized in Table 6.

The results of testing the significance of the profitability variable as a mediating variable using the Sobel test, Aroian test, and Goodman test. The results of profitability testing as a mediating effect of business risk on firm value are shown in Figure 2. Based on the results of testing shows that both the Sobel test, Aroian test, and Goodman test show the same decision that profitability significantly mediates the effect of business risk on firm value with a significance of 0.00 . 
Table 6 - The Total Effect of Business Risk, GCG, CSR on Profitability, and Company Value

\begin{tabular}{|c|c|c|}
\hline \multirow{2}{*}{ Independent Variable } & \multicolumn{2}{|c|}{ Dependent Variable } \\
\hline & Profitability & Corporate Value \\
\hline Business Risk & & \\
\hline Direct effect & 0,911 & 0,135 \\
\hline Indirect effect through profitability & & 0,403 \\
\hline Total effect & 0,911 & 0,538 \\
\hline GCG & & \\
\hline Direct effect & 0,058 & 0,165 \\
\hline Indirect effect through profitability & & 0,026 \\
\hline Total Effect & & 0,191 \\
\hline CSR & & \\
\hline Direct effect & 0,083 & $-0,048$ \\
\hline Indirect effect through profitability & & 0,037 \\
\hline Total effect & & $-0,011$ \\
\hline
\end{tabular}

Source: Data Processed.

\begin{tabular}{|c|c|c|c|c|}
\hline Input: & & Test statistic: & Std. Error: & $p$-value: \\
\hline a 1.3 & Sobel test: & 19.84616202 & 0.33472467 & 0 \\
\hline b 5.11 & Aroian test: & 19.84606842 & 0.33472625 & 0 \\
\hline$s_{\mathrm{a}} 0.004$ & Goodman test: & 19.84625562 & 0.33472309 & 0 \\
\hline$s_{\mathrm{b}} 0.257$ & Reset all & & Calculate & \\
\hline
\end{tabular}

Figure 2 - Results of Testing the Significance of Profitability Mediating Business Risk with Firm Value

The results of profitability testing as a mediating effect of GCG on firm value are shown in Figure 3. Based on the test results show that both the Sobel test, Aroian test, and Goodman test show the same decision that profitability significantly mediates the effect of GCG on firm value with a value of significance that is almost the same for Sobel test, Aroian test, and Goodman test, which is around 0.047.

\begin{tabular}{|c|c|c|c|c|}
\hline Input: & & Test statistic: & Std. Error: & $p$-value: \\
\hline a 0.078 & Sobel test: & 1.98995837 & 0.20029565 & 0.04659552 \\
\hline$b 5.11$ & Aroian test: & 1.98747151 & 0.20054627 & 0.04687017 \\
\hline$s_{\mathrm{a}} 0.039$ & Goodman test: & 1.99245459 & 0.20004471 & 0.0463212 \\
\hline$s_{\mathrm{b}} 0.257$ & Reset all & & Calculate & \\
\hline
\end{tabular}

Figure 3 - Test Results of the Significance of Profitability Mediating GCG with Firm Value

The results of profitability testing as a mediating effect of CSR on firm value are shown in Figure 4. Based on the results of testing shows that both Sobel test, Aroian test, and Goodman test show the same decision that profitability significantly mediates the effect of CSR on firm value with a significance value that is almost the same for Sobel test, Aroian test, and Goodman test, which is around 0.007 .

\begin{tabular}{|c|c|c|c|c|}
\hline Input: & & Test statistic: & Std. Error: & $p$-value: \\
\hline a 0.61 & Sobel test: & 2.67458454 & 1.16545204 & 0.00748219 \\
\hline$b 5.11$ & Aroian test: & 2.67126932 & 1.16689844 & 0.0075565 \\
\hline$s_{a} 0.226$ & Goodman test: & 2.67791213 & 1.16400384 & 0.00740827 \\
\hline$s_{\mathrm{b}} 0.257$ & Reset all & & Calculate & \\
\hline
\end{tabular}

Figure 4 - Test Results of the Significance of Profitability Mediating CSR with Firm Value 


\section{DISCUSSION OF RESULTS}

Based on the results of testing the structural model, the results of testing the research hypothesis can be summarized in Table 7

Table 7 - Research Hypothesis Testing Results

\begin{tabular}{|l|c|c|c|}
\hline \multicolumn{1}{|c|}{ Variable relationship } & Path Coef. & Sig, & Information \\
\hline Business risk $\rightarrow$ profitability & 0,911 & 0,000 & H1 accepted \\
\hline Business risk $\rightarrow$ Corporate Value & 0,135 & 0,535 & H2 rejected \\
\hline GCG $\rightarrow$ profitability & 0,058 & 0,048 & $\mathrm{H} 3$ accepted \\
\hline GCG $\rightarrow$ Corporate Value & 0,135 & 0,027 & $\mathrm{H} 4$ accepted \\
\hline CSR $\rightarrow$ profitability & 0,083 & 0,008 & $\mathrm{H} 5$ accepted \\
\hline CSR $\rightarrow$ Corporate Value & $-0,048$ & 0,549 & H6 rejected \\
\hline Profitability $\rightarrow$ Corporate Value & 0,442 & 0,049 & $\mathrm{H} 7$ accepted \\
\hline Business Risk $\rightarrow$ profitability $\rightarrow$ Corporate Value & 0,403 & 0,000 & $\mathrm{H} 8$ accepted \\
\hline GCG $\rightarrow$ profitability $\rightarrow$ Corporate Value & 0,026 & 0,047 & H9 accepted \\
\hline CSR $\rightarrow$ profitability $\rightarrow$ Corporate Value & 0,037 & 0,007 & H10accepted \\
\hline
\end{tabular}

Source: Data Processed.

Effect of business risk on profitability. Based on Table 7 shows that the effect of business risk on profitability has a coefficient of 0.911 with a significance of 0.00 . These results indicate that business risk has a significant positive effect on profitability, according to the research hypothesis. Thus the first hypothesis of this study was accepted.

The results of this study are consistent with the findings of Ayu (2014) and Wijaya (2011) that business risk has a significant positive effect on profitability. Business risk in this study was measured by the degree of operating leverage (DOL). DOL shows the relative changes in EBIT due to the relative changes in sales. DOL can be increased by changing the cost structure, where variable costs are converted to fixed costs by increasing fixed assets.

Chen (2018) found that operating leverage has a positive and significant effect on profitability. Banking as a service company can take advantage of high operating leverage because most of its assets are fixed assets. Operating leverage can increase company profitability if the company can achieve high economies of scale so that the average cost per product unit is low. The banking industry can increase operating leverage for example by utilizing the use of ATMs and providing e-banking services to reduce the need for employees as tellers.

Effect of business risk on company value. Based on Table 7 shows that the influence of business risk on firm value has a coefficient of 0.135 with a significance of 0.535 . These results indicate that business risk does not have a significant effect on firm value, not by the research hypothesis. Thus the second hypothesis of this study was rejected. The results of this study are not by the findings of Pertamawati (2015) and Roshinta (2016) having the result that Business Risk has a negative effect on Company Value. The tendency of investors will show a negative reaction in seeing information about the increased risk of a company and will cause a decrease in the value of the company.

The results of this study are consistent with the findings of Sari and Wijayanto (2015) that DOL does not influence firm value. Sari and Wijayanto (2015) state that this insignificant effect is because Investors are more concerned with aspects of how companies invest their funds in the form of asset investments in the hope of future profits. Investors can manage their investment risk by diversifying shares by buying shares in other sectors. This result also shows that banks can manage risk so as not to reduce the value of the company. Commercial bank health assessment by OJK takes into account risk factors. According to article 6 POJK no: 4 / POJK.03 / 2016 concerning the assessment of the soundness of commercial banks, it is stated that banks are required to conduct individual bank soundness assessments using a risk-based bank rating.

The effect of good corporate governance on profitability. Based on Table 7 shows that the effect of GCG on profitability has a coefficient of 0.058 with a significance of 0.048 . These results indicate that GCG has a significant positive effect on profitability, according to 
the research hypothesis. Thus the third hypothesis of this study was accepted.

The results of this study are by the findings of Ardi (2016) and Tjondro and Wilopo (2011) that GCG has a positive effect on profitability. Good Corporate Governance can increase company profitability because Good Corporate Governance can minimize the occurrence of conflicts of interest between majority and minority in a company. Conflicts of interest can be minimized so that managers can optimize profits because the better the quality of corporate profits will have an impact on increasing profitability.

The effect of good corporate governance on company value. Based on Table 7 shows that the influence of GCG on firm value has a coefficient of 0.135 with a significance of 0.027 . These results indicate that GCG has a significant positive effect on firm value, by the research hypothesis. Thus the fourth hypothesis of this study was accepted.

The results of this study are by the findings of Cheung et al. (2008) and Gurbuz, et al (2010), that the more qualified a company is in implementing GCG, it will increase the value of the company. The application of the principles of Good Corporate Governance (GCG) in a company can reduce conflicts of interest. Reducing conflicts of interest in a company can increase company value. Good Corporate Governance is also one measure of the performance of commercial banks according to POJK no: 4 / POJK.03 / 2016 regarding the rating of the soundness of commercial banks.

The effect of corporate social responsibility on profitability. Based on Table 7 shows that the influence of CSR on profitability has a coefficient of 0.083 with a significance of 0.008 . These results indicate that CSR has a significant positive effect on profitability, according to the research hypothesis. Thus the fifth hypothesis of this study was accepted.

The results of this study are by the findings of Byus, et al (2010), Ahmad and Sulaiman (2004) that CSR has a significant positive effect on profitability. Corporate Social Responsibility can increase profitability because it has an impact on a company's products able to be known by the public so that company profits will increase because the level of sales also increases. Public recognition is very important for the banking industry as a service company because the nature of intangible services and products cannot be seen directly by the public. Increased profits have a direct relationship to company profitability, where the relationship between profitability and CSR disclosure will show that social responsibility is needed to make the company gain profits in the future.

The effect of corporate social responsibility on company value. Based on Table 7 shows that the influence of CSR on company value has a coefficient of -0.048 with a significance of 0.549 . These results indicate that CSR has no significant effect on firm value, not by the research hypothesis. Thus the sixth hypothesis of this study was rejected.

The results of this study are not by the findings of Agustina (2013), Rustiarini (2010) and Kusumadilaga (2010), that CSR disclosure has a significant positive effect on firm value. Corporate social responsibility is a business strategy whose implementation takes into account all the interests of stakeholders. The application of CSR is related to the possibility of the company being accepted by the environment so that it will have an impact on the company's overall operational activities.

The results of this study are by the findings of Fiori, et al (2007) that CSR disclosure has no significant effect on firm value. Fiori et al. (2007) stated that this insignificant result was due to investor perceptions of low CSR, and the majority of investors were investmentoriented in the short term, while the impact of CSR had only occurred in the long term. Agustine (2014), found that CSR does not directly affect the value of the company. Investors in the Indonesian capital market tend to buy shares to obtain capital gains that usually buy and sell shares on a daily basis without regard to the company's long-term sustainability, whereas CSR is a long-term strategy of the company which means the influence of CSR cannot be directly felt in the short term (Agustine, 2014).

Effect of profitability on firm value. Based on Table 7 shows that the effect of profitability on firm value has a coefficient of 0.442 with a significance of 0.049 . These results indicate that profitability has a significant positive effect on firm value, by the research hypothesis. Thus the seventh hypothesis of this study was accepted.

The results of this study are consistent with the findings of Ardimas and Wardoyo 
(2014) and Wardoyo and Veronica (2013), that profitability has a significant positive effect on firm value. Profitability is an indicator of performance by management in managing the wealth of a company. Profitability will be able to increase the value of a company. By signaling theory, the greater the profitability of a company indicates a good company's prospects so that it can trigger investors to buy shares (Hardiyanti, 2012).

Profitability as a mediating effect of business risk on company value. Based on Table 7 shows profitability as a mediating effect of business risk on company value has a coefficient of 0.403 with a significance of 0,000 . These results indicate that profitability significantly mediates the effect of business risk on firm value, according to the research hypothesis. Thus the eighth hypothesis of this study was accepted. Business Risk is an incident of uncertainty in the company's activities on the level of returns or profits obtained in the future, while profitability can be an indicator of performance by management in managing the wealth of a company. Profitability will be able to increase the value of a company.

Profitability as a mediator of the influence of Good Corporate Governance on company value. Based on Table 7 shows profitability as a mediating effect of GCG on firm value has a coefficient of 0.026 with a significance of 0.047 . These results indicate that profitability significantly mediates the effect of GCG on firm value, by the research hypothesis. Thus the ninth hypothesis of this study was accepted.

Companies that have good governance will implement a more efficient corporate funding policy so that they can show a movement to increase profitability. Investors will see high profits can provide high returns so that investors' perceptions and interests in the company's shares also follow which is a reflection of company value (Hardiyanti, 2012).

Profitability mediates the effect of Corporate Social Responsibility on company value. Based on Table 7 shows profitability as a mediating effect of CSR on firm value has a coefficient of 0.037 with a significance of 0.007 . These results indicate that profitability significantly mediates the effect of CSR on firm value, according to the research hypothesis. Thus the tenth hypothesis of this study was accepted. Corporate Social Responsibility impacts the company's products can be known by the public so that the level of sales will increase and the company's profitability will also increase. CSR disclosure can increase the positive value of stakeholders. The value of the company will increase along with the increase in profitability of the company because the higher the profit the more interested investors invest their money in the company (Hardiyanti, 2012).

\section{CONCLUSION AND SUGGESTIONS}

Business risk has a significant positive effect on profitability. The results of this study indicate that banking companies on the IDX can manage risk well so that the risks that usually accompany business decisions do not harm the company. Banking companies can increase the degree of operating leverage as a way to increase profitability. Business risk has no significant effect on firm value. This result also shows that banks can manage risk so as not to reduce the value of the company. The banking industry is required to have a risk management policy because the implementation of risk management policies is one of the standard components of the performance evaluation of commercial banks by OJK. GCG has a significant positive effect on profitability. Good Corporate Governance can increase company profitability because Good Corporate Governance can minimize the occurrence of conflicts of interest between majority and minority in a company. Conflicts of interest can be minimized so that managers can optimize profits because the better the quality of corporate profits will have an impact on increasing profitability. GCG has a significant positive effect on firm value. The application of GCG principles can reduce conflicts of interest between stakeholders. Reducing conflicts of interest can increase company value. The banking industry is required to implement GCG because it is one of the standard components of commercial bank performance evaluation by the OJK. CSR has a significant positive effect on profitability. The impact of implementing CSR is that a company's product can be recognized by the public so that the level of sales and profits also increase. Public recognition is very important for the banking industry as a service company because the 
nature of intangible services and products cannot be seen directly by the public every day.

CSR has no significant effect on firm value. This insignificant result is due to the low investor perception of CSR. The majority of investors in the Indonesian capital market investments in the short term, while the impact of CSR has only occurred in the long term. Profitability has a significant positive effect on firm value. Profitability will be able to increase the value of a company. In accordance with signaling theory, the greater the profitability of a company indicates a good company's prospects so that it can increase the value of the company. Profitability significantly mediates the effect of business risk on firm value. Every business policy that aims to make a profit is always followed by risk. The success of bank management in managing risks will increase profitability and subsequently increase company value. Profitability significantly mediates the effect of GCG on firm value. Good GCG implementation will balance the fulfillment of the interests of all company stakeholders. The implementation of GCG in the banking industry improves banking performance and subsequently increases company value. Profitability significantly mediates the effect of CSR on firm value. CSR has an impact on increasing public awareness of the company's existence so that the level of sales will increase and the company's profitability will also increase. CSR disclosure can increase the positive value of stakeholders, thereby increasing the value of the company.

Suggestions that can be given to various parties as a contribution to the results of this study that might be realized are investors can pay attention to financial statements, especially Return On Assets and composite value of GCG self assessment according to Bank Indonesia as a basis for investing in banking companies, because it is proven that profitability and GCG significant positive effect on company value. For bank management, the results of this study can be taken into consideration in making every business decision, to pay attention to their impact on bank profitability. Profitability, in addition to having a direct impact on company value, also significantly mediates the effect of business risk, GCG, and CSR on corporate value. Thus, for the implementation of risk management, GCG, and CSR to increase the value of the company, it must be followed by increased profitability.

\section{REFERENCES}

1. Ahmad, Nik Nazli Nik and Maliah Sulaiman. (2004). "Environmental Disclosures in Malaysian Annual Reports: A Legitimacy Theory Perspective". International Journal of Commerce and Management, 4, 14-44.

2. Agustina, Silvia. 2013 "Pengaruh Profitabilitas and Pengungkapan Corporate Social Responsibility terhadap Nilai Perusahaan (Studi Empiris pada Perusahaan Manufaktur yang Terdaftar di Bursa Efek Indonesia)". Artikel Penelitian. Padang: Fakultas Ekonomi UNP.

3. Agustine, I. 2014. Pengaruh Corporate Social Responsibility Terhadap Nilai Perusahaan. Jurnal Finesta. Vol. 2 (1): 42-47.

4. Ayu and Yadnya. 2014. Pengaruh Ukuran Perusahaan and Business Risk Terhadap Profitabilitas Serta Kebijakan Deviden. Fakultas Ekonomi and Bisnis Universitas Udayana.

5. Brigham, Eugene F. and Joel F. Houston. (2001). Manajemen Keuangan II. Jakarta: Erlangga

6. Byus, Kent, Donald Deis, and Bo Ouyang. (2010). Doing Well by Doing Good: Corporate Social Responsibility and Profitability. Advanced Management Journal, 2, 44-55

7. Crisostomo, Vicente Lima, Fatima de Souza Freire, and Felipe Cortes de Vasconcellos. (2011). Corporate social responsibility, firm value and financial performance in Brazil. Social Responsibility Journal, 7, 295-309.

8. Enggal Sriwardiningsih. 2010 "Dampak Penularan Krisis Global Terhadap Aliran Investasi Asing Di Indonesia" Jurusan Manajemen, Fakultas Ekonomi and Bisnis, Universitas Bina Nusantara, 
9. Fiori, Giovanni, Donato, Francesca di, and Izzo, Maria F. 2007. Corporate Social Responsibility and Firm Performance, Analysis on Italian Listed Companies. Luiss Guido Carli University, Italy.

10. Gurbuz, Osman, Asli Aybars, and Ozlem Kutlu. (2010). Corporate Governance and Financial Performance with a Perspective on Institutional Ownership: Empirical Evidence from Turkey. JAMAR, 8(2), 21-37.

11. Hardiyanti, Nia. 2012. Analisis Pengaruh Insider Ownership, Leverage, Profitability, Firm Size and Dividen Payout Ratio terhadap Nilai Perusahaan (Studi Pada Perusahaan Manufaktur yang Terdaftar di BEI tahun 2007-2010). Universitas Diponegoro, Semarang.

12. Hidayah, Nurul. 2014. The Effect of Company Characteristic Toward Firm Value In The Property And Real Estate Company In Indonesia Stock Exchange. International Journal of Business, Economics, and Law, 5(1): 1- 8.

13. Ragers, S. Hayibor, and Beagle. (2009). The Relation between Good Corporate Governance, Financial Performance and Market Performance. Business and Society, 4, 110-127

14. Sugiyono. 2010. Metode Penelitian Bisnis. Bandung: Alfabeta

15. Susanti, Serli Ike Ari. 2011. Pengaruh Kualitas Corporate Governance, Kualitas Audit, and Earnings Management Terhadap Kinerja Perusahaan. Jurnal Ekonomi and Bisnis, 5(2): h: 145-161.

16. Susilowati. (2008). Pengaruh Corporate Social Responsibility terhadap Profitabilitas. Jurnal Riset Akuntansi Universitas Islam Indonesia, 6, 150- 159

17. Suyana Utama, Made. 2009. Aplikasi Analisis Kuantitatif. Denpasar: Sastra Utama.

18. Tanudjaja, Bing Bedjo. (2006). Perkembangan Corporate Social Responsibility Di Indonesia. UK Petra Journal, 8(2).

19. Tikawati. 2016. Pengaruh Corporate Governance, Growth Opportunity and Net Profit Margin (Npm) Terhadap Nilai Perusahaan (Studi Empiris pada Perusahaan Go Public di Bursa Efek Indonesia Tahun 2008-2011). Jurnal Ekonomi and Bisnis Islam. 02(01): 1026.

20. Untung, Hendrik Budi. 2008. Corporate Social Responsibility. Jakarta: Sinar Grafika.

21. Wardoyo and Theodora Martina Veronica, 2013.Pengaruh Kinerja Keuangan, Good Corporate Governance and Corporate Social Responsibility terhadap Nilai Perusahaan. Jurnal Dinamika Manajemen Vol. 4, No. 2, 2013, pp: 132-149. 